\section{Folkets helsemelding}

\section{Fugelli P, Ingstad B.}

Helse på norsk

God helse slik folk ser det. $495 \mathrm{~s}$

Oslo: Gyldendal Akademisk, 2009. Pris NOK 495 ISBN 978-82-41-71125-1

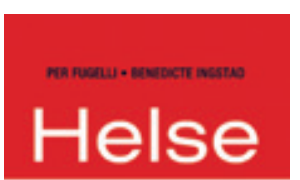

Dette skal være «folkets egen helsemelding». Forfatterne vil den skal fremstå som PÅ norsk et alternativ og et supplement til offisielle rapporter, publikasjoner og statusmeldinger fra offentlige organer og organisasjoner - en motmelding til det som kommer fra epidemiologene og andre fageksperter.

En professor i sosialmedisin og markert samfunnsdebattant har alliert seg med en nestor innen norsk medisinsk antropologi. Sammen har de foretatt kvalitative intervjuer av 80 personer. De har besøkt fem lokalsamfunn i Norge: et fiskevær nordpå, en kystsmåby i Sør-Norge, en bydel i Oslo, en fjellbygd på Østlandet og en vestlandsbygd med jordbruk og industri. Mulige intervjuobjekter ble foreslått av nøkkelpersoner i lokalsamfunnet. I tillegg har de snakket med 14 tidligere eller nåværende toppidrettsutøvere. I intervjuene er det lagt vekt på å få frem oppfatninger om begrepet «helse». Hva er egentlig god helse? Videre er det samtalt om forholdet mellom helse og dimensjoner som kropp, natur og miljø, livsstil, personlige egenskaper, familie og nærmiljø, arbeid, økonomi, politikk, helsetjeneste og religion. Forfatterne har kunnet relatere sine funn i Norge til observasjoner de har gjort i møte med mennesker i en ekstremt annen livssituasjon - San-folket i Kalahari-ørkenen.

Forskernes materiale er systematisert og drøftet i forhold til et omfattende teoretisk rammeverk. Litteraturhenvisningene alene utgjør 30 sider. Dette har ikke gått på bekostning av tilgjengeligheten for personer utenfor deres eget fagfelt. Språket er lødig, uten barrierer knyttet til faglig stammedialekt og fremmedord. Slik sett ligger det til rette for at forfatternes intensjon kan realiseres, at boken skal kunne leses både av et bredt publikum, av politikere og av helsepersonell.
Likevel tror jeg dette mer blir et referanseverk enn det blir folkelesning og en utgivelse som studeres fra perm til perm. Selv om teksten er brutt opp med lyriske kapittelprologer, underkapitler og punktvis fremstilling, gir den gir et ganske massivt inntrykk med nesten 500 tekstsider uten illustrasjoner og knapt nok en tabell.

Intervjuene ble foretatt i slutten av 1990årene. Man kan stille spørsmålet om resultatene ville blitt de samme i 2010. Det har skjedd mange endringer i det norske samfunnet siden den gang som kan ha påvirket folks syn på helsen, for eksempel bruken av moderne informasjonsteknologi. Begrepet «norsk» blir også mer problematisk etter hvert som landet blir stadig mer multietnisk og multikulturelt.

På tross av disse forbeholdene vil Helse på norsk få en sentral plass i min samfunnsmedisinske bokhylle. Jeg anbefaler både mine fagkolleger og andre med interesse for helseforhold i landet vårt å anskaffe den. Min erfaring er at den bør fordøyes i mindre doser eller brukes som referanseverk, eksempelvis dersom man vil vite mer om forholdet mellom religion og folkets egen helse - et lite omtalt tema i medisinsk faglitteratur.

\section{Kristian Hagestad}

Helse- og omsorgsavdelingen

Fylkesmannen i Vest-Agder

Kristiansand

\section{Vejviser for medisinske studenter og yngre læger}

Vaglum P

\section{Legens utfordringer}

Om følelsesmessige sider ved legeyrket. $242 \mathrm{~s}$. Oslo: Gyldendal Akademisk, 2009. Pris NOK 275 ISBN 978-82-05-39623-4

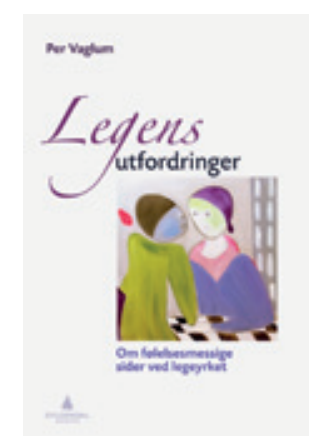

Når medicinske studenter og yngre læger i egne lægeroller møder medicinens målgrupper: patienter og pårørende, er det også et møde imellem overbegreberne «læger» og «patienter»som synes selv-definerende. Men virkeligheden rummer i begge grupper en meget stor variation. I patientgruppen endog inden for alle diagnosegrupper og i egen lægerolle variationer inden for specialer, menneskesyn, etik og moral, og inden for de sidste især forholdet imellem ansvaret for individualitet og kollektivitet.

Derfor er denne nye bog så nødvendig og nyttig som supplement til lærebøger og forelæsninger, fordi disse ofte i fremstillingsformen lider under de vidtspændende overbegrebers begrænsninger og tyranni. Og selv om bogen primært sigter mod medicinske studenter og turnuslæger, er dens sekundære målgruppe alle lager, fordi de som postgraduate pædagoger er en del af senior-målgruppen, som også uden for en formaliseret underviservirksomhed alle fungerer som positive eller negative rollemodeller for de unge i faget.

Per Vaglum har med sin store personlige erfaring taget pædagogisk udgangspunkt i filosoffen Søren Kierkegaard's udsagn, «At man, naar det i Sandhed skal lykkes En at føre et Menneske hen til et bestemt Sted, først og fremmest maa passe paa at finde ham der hvor han er og begynde der». Og sker det, stimuleres læserens motivation og fastholder ham dér.

Elegant omsætter Per Vaglum dette i den valgte form: dobbeltkapitler i først teori og så i parallelkapitlet mødet med emnets virkelighed i meget kunstnerisk originale mini-dramatiske noveller, så en dansk anmelder håber på tilgivelse for endnu et dansk citat: N.F.S. Grundtvig's «at virkeligheden er altings prøve».

Når man selv i universitetspædagogikken har anvendt kunsten som øjenåbner for studenter og læger, er Per Vaglum's indsats bevægende, med titlerne fra Snøstormen og til Mari, du bedåre. Og når man kommer til kapitel 13 og 14, hvor øjet rettes mod fremtidens sundhedsvæsen, værdsætter man atter forfatterens mod og kunstneriske evner og originalitet. Hvis anmelderen endnu en gang tilgives en egennational vurdering, er konklusionerne, at lignende dilemmaer er kendt andre steder fra i Norden, så stærkt at henvise til, at anmelderen i 1970'erne tilførte det danske sprog et nyt ord, «djøficering», ved den sundhedspolitiske og økonomiske indtrængen i sundhedsvæsenet af DJØF (Danmarks Jurist- og Økonomforbund). Begrebet har fået sproglig indfødsret i dansk, men truslerne via begrebet er $i$ dag mindsket. 